\title{
Molecular phylogeny of Daucus (Apiaceae): Evidence from nuclear ribosomal DNA ITS sequences
}

\author{
Byoung Yoon Lee ${ }^{1, *}$ and Chong-Wook Park ${ }^{2}$ \\ ${ }^{1}$ Division of Plant Resources, National Institute of Biological Resources, Incheon 404-170, Korea \\ ${ }^{2}$ School of Biological Sciences, Seoul National University, Seoul 151-747, Korea \\ *Correspondent: bylee80@korea.kr
}

\begin{abstract}
The Apiaceae genus Daucus consists of approximately 25 species (including carrots) which are characterized by the presence of bracts in pedunculate umbels, dorsally compressed mericarps, hairs on primary ridges, and uniseriately arranged spines on the secondary ridges of the fruit. Taxonomically, Daucus has been considered to be one of the most problematic genera in the Apiaceae due to the highly variable fruit morphology. Despite taxonomic controversy and economic importance of the genus, no rigorously constructed estimate of phylogenetic relationships exists. To examine generic limit and relationships among species of Daucus and its putatively related taxa, phylogenetic analyses of characters derived from nuclear ribosomal DNA ITS sequences were conducted. Two major clades emerged within Daucus, but neither of them have been previously recognized using morphological characters. The phylogeny also provides taxonomic status of recently reported new species of Daucus, D. arcanus and D. conchitae.
\end{abstract}

Keywords: Apiaceae, Daucus, ITS, Umbelliferae

(C) 2014 National Institute of Biological Resources

DOI: 10.12651/JSR.2014.3.1.039

\section{INTRODUCTION}

The genus Daucus L. (Apiaceae Lindl.) is defined morphologically by a suite of easily observed and well-known characters, including dorsally compressed mericarps, hairs on primary ridges, and singly arranged spines on the secondary ridges of the fruit (Okeke, 1978). The genus is mainly distributed in Europe including the Mediterranean regions, southwestern and central Asia, and tropical Africa. A few species are also found in the other continents; D. glochidiatus (Labill.) Fischer \& C.A. Mey. is restricted to Australia and New Zealand, D. montanus Humb. \& Bonpl. ex Spreng. to central and South America, and D. pusillus Michx. to North and South America (Heywood, 1983). The genus is economically important; it includes the common carrot, Daucus carota L. ssp. sativus (Hoffm.) Arcang., a root crop which is widely cultivated in most parts of the world. The carrot is medicinally important as stimulant, deobstruent, and excitant and also valuable for other urinary problems, skin affliction, jaundice, dropsy, and uterine ailments (Heywood, 1978; Okeke, 1978).

Taxonomically, Daucus and other spiny-fruited genera (e.g., Caucalis L., Torilis Adans., and Orlaya Hoffm.) were treated into tribe Caucalideae Tausch on the basis of the unique presence of spines, hooks, tubercles, or bristly hairs on the primary and/or secondary ridges of their fruits (Bentham and Hooker, 1867). This is in contrast to Drude (1898), who distributed these spiny-fruited plants into tribe Dauceae and tribe Scandiceae subtribe Caucalidinae. Drude believed that members of Dauceae were allied to plants in his tribe Laserpitieae, whose members have fruits without spines but with primary and prominent secondary ridges. Koso-Poljansky (1916; 1917), following Drude's segregation of the spiny-fruited umbles into Dauceae and Caucalidinae, expanded tribe Dauceae including many representatives of Drude's Laserpitieae. However, all the spiny-fruited taxa (e.g., Drude's Dauceae and Scandiceae subtribe Caucalidinae) were united as a single tribe Caucalideae on the basis of phytochemistry and micro-characters of fruits using scanning electron microscopy (Heywood and Jury in Heywood, 1982) whereas the tribe Laserpitieae was retained as an independent tribe (Heywood, 1978).

Infrageneric classification of Daucus L. largely based on anatomical and morphological features of the mature fruit has been also controversial. The genus Daucus were variously divided into sections, subgenera, or some species of the genus were even treated into separated genera, 
based on anatomical and morphological features of the flower and fruit (Drude, 1898; Calestani, 1905; Thellung, 1926). Thellung (1926), in his worldwide monograph of Daucus, recognized six sections (i.e. Anisactis DC., Leptodaucus Thell., Carota [=Daucus], Platyspermum DC., Pseudoplatyspermum Thell., and Chrysodaucus Thell.) based on morphological and anatomical features of the flower and fruits including length of styles, stylopodia, petals, and vittae size and shape. However, his treatment was based on the limited materials available at that time and his descriptions lacked detailed information on some important features of fruits. On the other hand, Okeke (1978) divided the genus Daucus into four sections; Meiodes, Daucus, Platyspermum, and Anisactis. He recognized sect. Leptodaucus as a subsect. of sect. Daucus, suggesting that species belonging to Leptodaucus might be intermediates between sects. Daucus and Anisactis. In addition, Okeke (1978) treated sects. Pseudoplatyspermum and Chrysodaucus as subsects. of sect. Platyspermum, suggesting that subsect. Platyspermum might be an intermediate between subsects. Pseudoplatyspermum and Chrysodaucus. Latetr, Sáenz (1981) followed Thellug's (1926) system in general, but placed species belonging to sect. Leptodaucus and D. crinitus of Meoides into sect. Daucus on the basis of the triangular shape of vittae. Heywood (1982), however, elevated all the subsections Okeke (1978) treated to sectional status and recognized seven sections of the genus Daucus; Anisactis, Chrysodaucus, Daucus, Leptodaucus, Meoides, Platyspermum, and Pseudoplatyspermum. Although twenty-one species were reported to be members of Daucus (Heywood, 1982), it is difficult to determine the exact size of the genus because of disagreements about the delimitation of the species. If slight variations in the subspecies of Daucus carota L. were considered to be important for recognition of species, number of species within Daucus increased up to about sixty species (Cheeseman, 1925; Zohary, 1972). Two more species have been also reported in Europe as new taxa; D. arcanus Garcia and Silvestre, and D. conchitae Greuters in the Heywood's (1982) checklist of the genus.

Recently, several studies have demonstrated that the utility of molecular data in examining evolutionary relationships of the spiny-fruited umbels using nuclear rDNA ITS sequences (Lee and Downie, 1999) and cpDNA restriction sites (Lee and Downie, 2000). These studies implied that the genus Daucus may not be monophyletic: several other genera including Pseudorlaya Murb. and Agrocharis Hochst. were nested within the genus Daucus. Unfortunately, the purpose of each of these studies was not to resolve the infrageneric relationships within the specific genus but rather to infer the higher-level groupings within the family or tribes. Therefore, they did not address generic limits, especially in the larger genera such as Daucus because of the limited number of species investigated.

As part of investigations on the evolutionary relationships of the genus Daucus, we have examined nuclear ribosomal DNA ITS sequences of 35 taxa belonging to Daucus, Pseudorlaya, and Agrocharis. Our objectives are as follows: (1) to delimit a generic boundary of the genus Daucus; (2) to ascertain phylogenetic relationships of the seven sections within Daucus; (3) to determine the taxonomic position and status of the newly reported species of Daucus.

\section{Materials And Methods}

\section{Terminal taxa}

Twenty-six accessions from 18 species of Daucus, all three species of Pseudorlaya, all four species of Agrocharis, and monotypic Pachyctenium Maire \& Pamp. ex Pamp. were examined for ITS sequence variation (Table 1). In addition, one accession of Agrocharis pedunculata (Baker) Heywood \& Jury collected in Tanzania without glochidiate apex of the secondary spines was included. In total, 35 accessions were considered in this study. Three species of Orlaya (i.e; O. daucoides (L.) Greuter, O. daucorlaya Murb., and O. grandiflora (L.) Hoffm.) and Laserpitium hispidum M. Bieb. were used to root the trees based on previous taxonomic schemes and previously reported nuclear ITS- and cpDNA-derived phylogenies (Lee and Downie, 1999; 2000; Downie et al., 2000).

\section{Experimental strategy}

Leaf materials for DNA extraction were obtained either directly from the field, from plants cultivated from seeds in the greenhouse, or from accessioned plants cultivated at several botanic gardens. For some species, DNAs were extracted from herbarium specimens. All plants were identified using published keys and comparison to herbarium specimens. Details of the DNA extraction procedures have been presented in Lee and Downie (1999). Double-stranded DNAs of the complete ITS region in each genomic DNA were amplified by the PCR (polymerase chain reaction) technique using primers "ITS 5" and "ITS 4" in an equimolar ratio (White et al., 1990). For some DNAs extracted from herbarium materials, optimum amplification was achieved when the template DNA was diluted $1: 100$ or when the concentration of $\mathrm{MgCl}_{2}$ was increased from $1.5 \mathrm{mmol} / \mathrm{L}$ to $3.0 \mathrm{mmol} / \mathrm{L}$. Successful PCR amplifications resulted in a single DNA band corresponding to approximately $700 \mathrm{bp}$ in size. The sequence data were obtained using both Applied Biosystem (Foster City, California, USA) 310 Automatic DNA sequencer with Stretch upgrade and manual sequencing. 


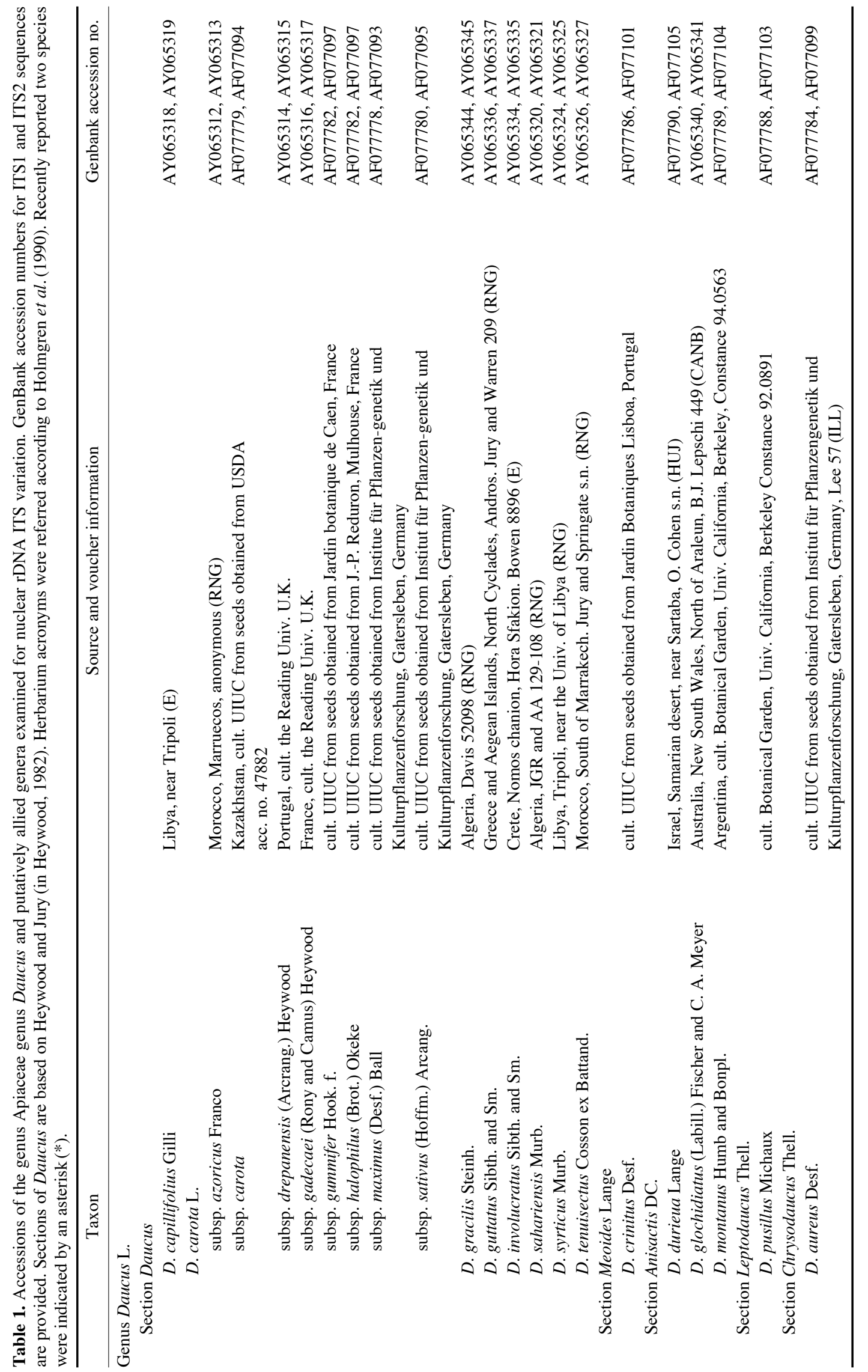




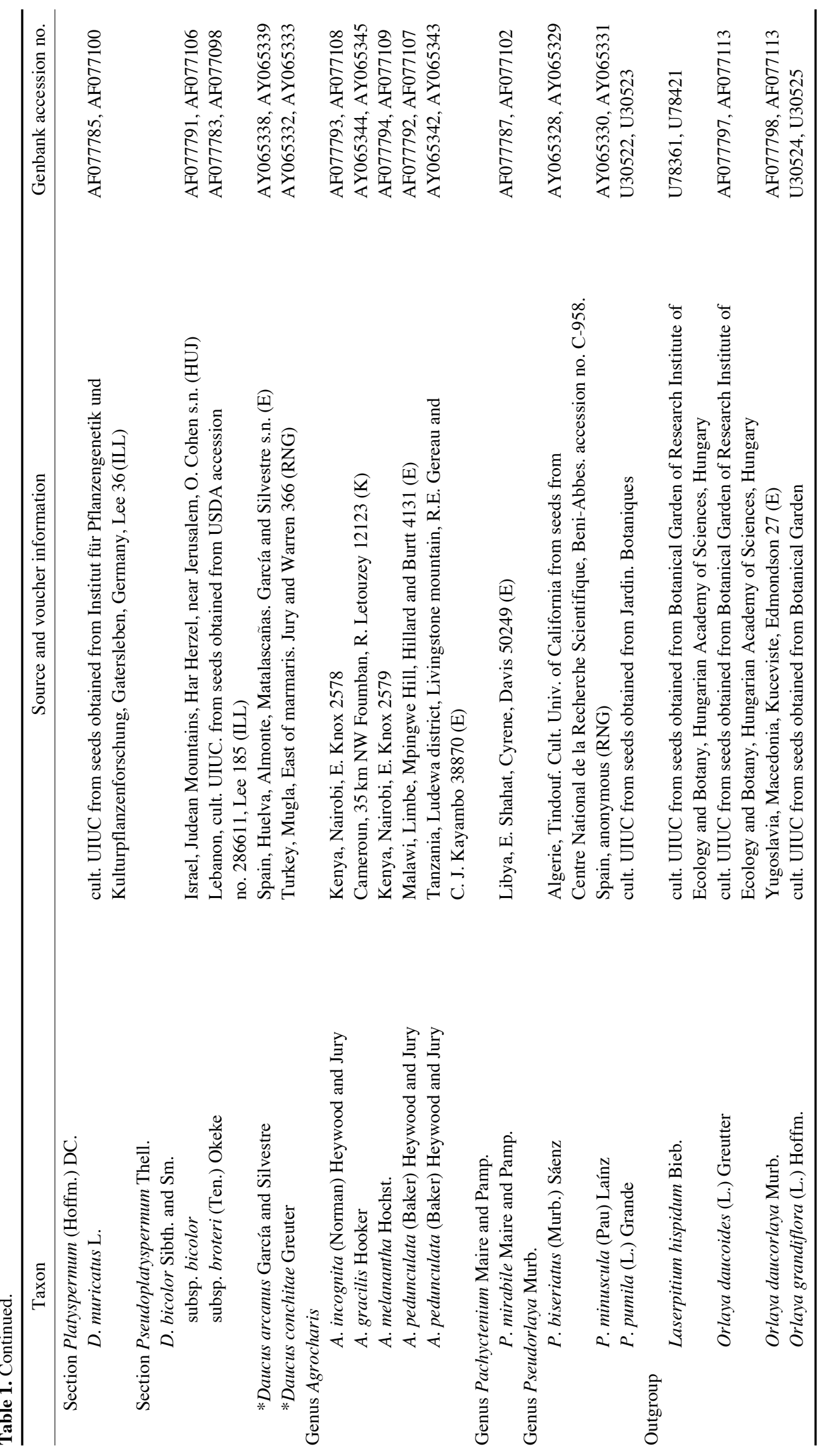


Cyclic sequencing reactions were carried out in a PTC100 thermocycler (M. J. Research, Cambridge, Massachusetts, USA) using the purified PCR products. Ampli Taq DNA polymerase, and fluorescent dye-labeled terminators (Perkin-Elmer, Norwalk, Conneticut, USA). All automated and manual- sequenced outputs were checked visually and edited for correct automated base-calling.

\section{Phylogenetic analyses}

Only ITS 1 and ITS 2 regions were included in the analysis since sequence data for the intervening $5.8 \mathrm{~S}$ subunit were incomplete for many taxa, and those data available were not sufficiently variable. DNA sequences were aligned using CLUSTAL V (Higgins et al., 1992), adjusted manually where necessary, and imported into PAUP* version 4.0b4a (Swofford, 2000). Only those positions that were in obvious alignment were used in the distance calculations and phylogenetic analyses. Pairwise nucleotide differences of unambiguously aligned positions were determined using the distance matrix option in PAUP*. In the phylogenetic analysis, all gaps were treated as missing data. Transition/transversion (Ts/Tv) ratios were calculated using MacClade (version 3.0; Maddison and Maddison, 1992) across all maximally parsimonious trees obtained. The ITS data were analyzed initially using maximum parsimony (MP). All heuristic searches were conducted with 100 random addition replicates and tree bisection-reconnection branch swapping. The options mulpars, steepest descent, collapse, and acctran optimization were selected. To assess the relative support for each clade, bootstrap values (Felsenstein, 1985) were calculated from 100 replicate analyses using the heuristic search strategy and simple addition sequence of taxa. To complete the decay analysis, the computer program AutoDecay (Erikkson, 1997) was used, following the converse-constraint method (Baum et al., 1994). The amount of phylogenetic information in the parsimony analysis was estimated using the consistency (CI; Kluge and Farris, 1969) and retention (RI; Farris, 1989) indices. Distance trees were constructed using the neighbor-joining (NJ) method (Saitou and Nei, 1987), implemented using the Neighbor program in Felsenstein's (1993) PHYLIP (version 3.572). Distance matrices were calculated using the DNADIST program of PHYLIP, and the numbers of nucleotide substitutions were estimated using Kimura's (1980) two parameter method. A bootstrap analysis of the data was done using 100 resampled data sets generated using the SEQBOOT program prior to calculating the distance matrices and neighbor-joining trees. PHYLIP's CONSENSE program was then implemented in order to construct a strict consensus tree. The maximum likelihood (ML) method was also applied to these ITS data using the program fastDNAml (version 1.0.6; Olsen et al., 1994), based on the procedures of Felsenstein (1981). ML tree was inferred using a $\mathrm{Ts} / \mathrm{Tv}$ rate ratio of 1.6 , randomizing the input order of sequences (jumble), and by invoking the global branch swapping search option.

\section{Results}

\section{Sequence divergence}

The ITS region in Daucus and putatively related genera ranges from 438 to $442 \mathrm{bp}$; these sizes are comparable to sizes reported in other Apiaceae genera (Downie and Katz-Downie, 1996; Katz-Downie et al., 1999; Downie et al., 2000). On average, the ITS1 region (216.87 bp in size) is slightly shorter than the ITS2 region (223.26 bp). Alignment of all 39 complete ITS1 and ITS2 sequences resulted in a matrix of 468 nucleotide positions. Of the 468 initial alignment positions, 40 positions (approximately $8.5 \%$ of the sequences) were deleted due to alignment ambiguities. Of the remaining 428 unambiguously aligned positions, $145(33.9 \%)$ were potentially parsimony informative, $214(50.0 \%)$ were constant, and $69(16.1 \%)$ were unique to individual taxa. In direct pairwise comparisons of unambiguous positions among all 39 accessions, sequence divergence values ranged from identity to $22.2 \%$ of nucleotides in ITS1 and from identity to $24.2 \%$ of nucleotides in ITS2. Comparisons of sequence pairs across both spacer regions gave divergence values ranging from identity among four subspecies of $D$. carota (subsp. halophilus, subsp. gummifer, subsp. azoricus, and subsp. gadecaei) to $21.5 \%$ between Daucus guttatus and Orlaya daucoides. Within the genus Daucus, sequence divergence values ranged from identity to $17.1 \%$ between $D$. guttatus and D. aureus or D. muricatus. Variation in the ITS sequences of recently established new species was not extensive and indicated a close homology with its putatively related taxa; $0.73 \%$ between $D$. arcanus and $D$. pusillus, $0.48 \%$ between $D$. involucratus and $D$. conchitae.

\section{Phylogenetic analysis}

Parsimony analysis of 39 combined ITS1 and ITS2 sequences resulted in 11 minimal length trees; the strict consensus of these trees, with accompanying bootstrap and decay values, is presented in Fig. 1. Each of these trees had a length of 431 steps, CI's of 0.6613 and 0.5817 (with and without uninformative characters, respectively), and a RI of 0.8387 . The neighbor-joining tree, calculated with a Ts/Tv rate ratio of 1.6 based on the actual inferred frequencies determined over all 11 maximum parsimony trees by MacClade, is presented in Fig. 2. On this tree, bootstrap values $<20 \%$ are not indicated. The same topology resulted when $\mathrm{Ts} / \mathrm{Tv}$ rate ratio of 1.0 or 


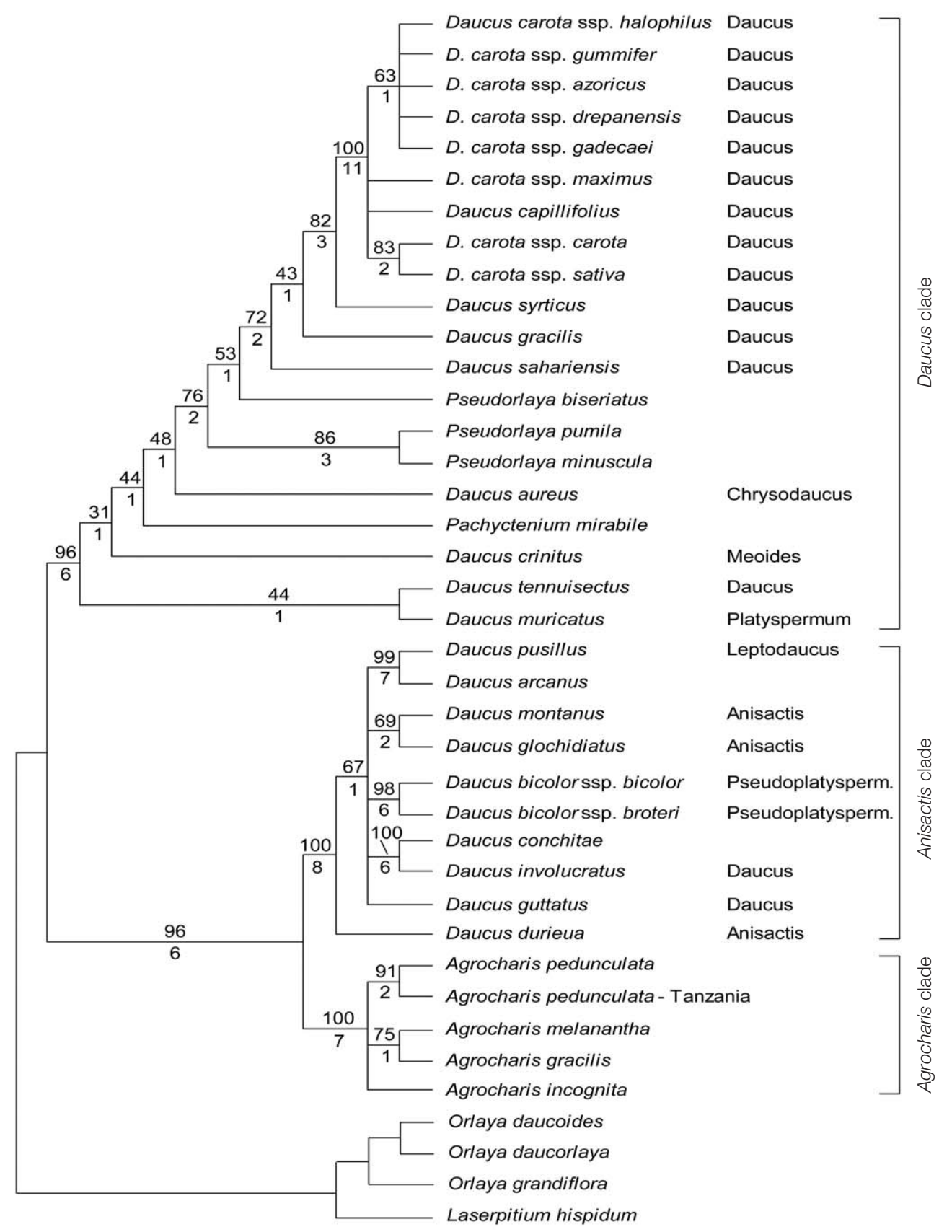

Fig. 1. Strict consensus of 11 parsimony trees derived from equally-weighted parsimony analysis of combined nuclear DNA ITS1 and ITS2 sequences from Daucus and its relatives using all unambiguously-aligned positions (CIs with and without uninformative characters= 0.6613 and $0.5817 ; \mathrm{RI}=0.8387$ ). From the left to the right, names of taxa, sections, and clades are given. Numbers above the nodes indicate the number of times a monophyletic group occurred in 100 bootstrap replicates; AutoDecay values are given below.

2.0 were used. The best maximum likelihood tree, also calculated with a Ts/Tv rate ratio of 1.6 , had a long likelihood value of -2938.56 .

\section{Phylogenetic resolutions}

Phylogenies estimated using maximum parsimony, neighbor-joining, and maximum likelihood methods give essentially similar topologies, with those few areas of discord noted below. In each of these trees, three major clades of taxa are clearly discernable with high values of bootstrap and decay. The first group includes the species, Daucus carota, D. capillifolius, D. syrticus, D. gracilis, D. sahariensis, three species of Pseudorlaya (P. biseria- 


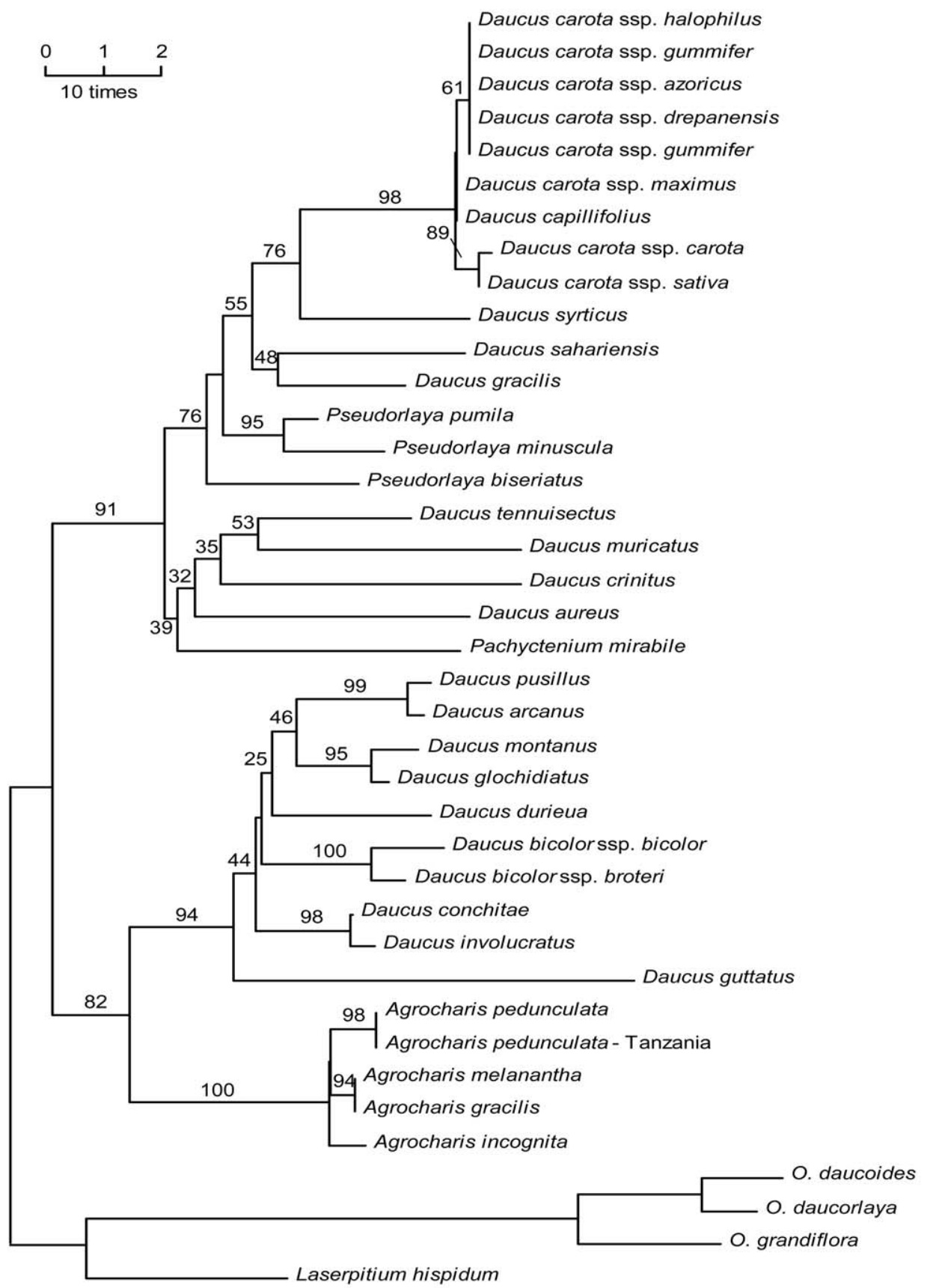

Fig. 2. Neighbor-joining tree inferred form the analysis of 39 nuclear rDNA ITS1 and ITS2 sequences from Apiaceae genus Daucus and its relatives using a transition/transversion rate ratio of 1.6. Branch lengths are proportional to distance estimated from the two parameter method of Kimura. Numbers at nodes indicate bootstrap values for 100 replicate analyses. On this tree, bootstrap values $<20 \%$ are not indicated.

tus, P. pumila, and P. minuscula), D. aureus, Pachyctenium, D. crinitus, D. tenuisectus, and D. muricatus. The second group includes Daucus pusillus, D. arcanus, D. montanum, D. glochidiatus, D. bicolor, D. conchitae, $D$. involucratus, D. guttatus, and D. durieua. The third group is consisted exclusively of species of Agrocharis (A. pedunculata, A. incognita, A. melanantha, and A. gracilis).
We have named these three groups the Daucus, Anisactis, and Agrocharis clades, respectively (Figs. 1, 3). The close relationship between our second and third clades is largely congruent as a result of each of the phylogenetic analyses. With regard to the Daucus clade, D. carota, represented herein by eight subspecies, is not monophyletic due to inclusion of north African D. capillifolius within 


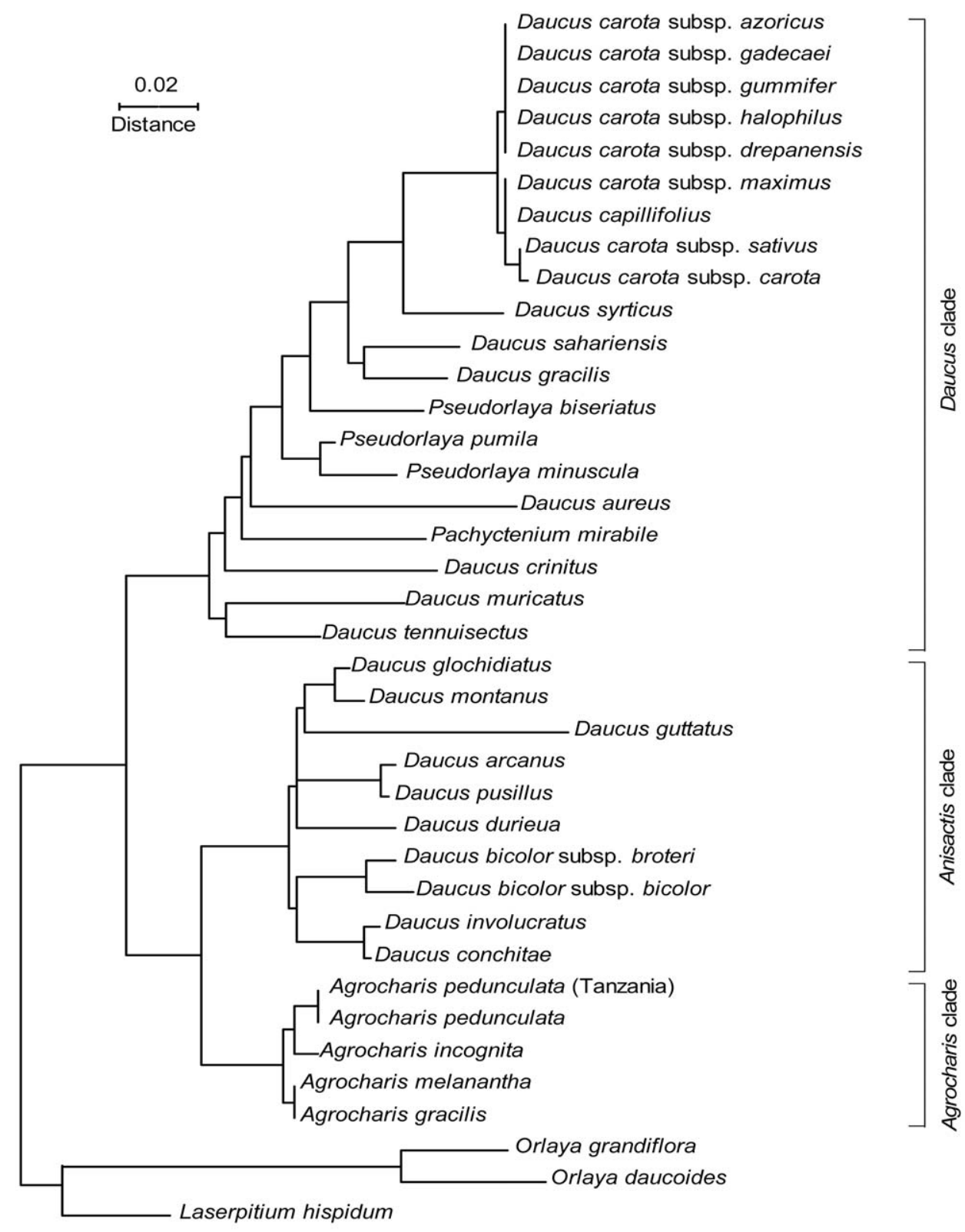

Fig. 3. Maximum likelihood tree constructed from 38 nuclear rDNA ITS1 and ITS2 sequences from Apiaceae genus Daucus and relatives using a transition/transversion rate ratio of 1.6. Branch lengths are proportional to the number of expected nucleotide substitutions per site.

the species. This subclade, in turn, is sister to Daucus syrticus. Next is $D$. gracilis, followed by $D$. sahariensis. $D$. gracilis and D. sahariensis ally weakly in both $\mathrm{NJ}$ and ML trees (Figs. 2,3) but not in the MP tree (Fig. 1). Pseudorlaya arises next, but not monophyletic because P. biseriatus is placed outside from the genus. Daucus aureus, D. crinitus, and Pachyctenium each arises separately forming unresolved branches in the MP tree whereas $D$. muricatus and D. tennuisectus ally in all MP, NJ, and ML trees. Within the Anisactis clade, four paired groups are evident. Each of these groups with the exception of a group comprising D. montanus and D. glochidiatus is supported by a high bootstrap value. D. guttatus is variably positioned depending upon the method of tree construction used. In the MP tree, D. guttatus arises as an independent branch of a polychotomy, whereas it is sister to all other taxa within the Anisactis clade in the NJ tree (Fig. 2). In the other hand, D. guttatus is sister to a small clade comprising D. glochidiatus and D. montanus in the ML tree (Fig. 3). Daucus conchitae, newly establisehd from Turkey, is closely related to $D$. involucratus. Surprisingly, the close relationship between American $D$. pusillus and another new species from Spain, D. arcanus, is strongly supported by high bootstrap values (99\% in 
both MP and NJ trees). However, two species (D. pusillus and $D$. montanus) with a closer continental relationship between South and North America fail to form a clade. South American D. montanus allies with Australian D. glochidiatus, not North American D. pusillus in all trees constructed. The monophyly of the tropical African Agrocharis is strongly supported by $100 \%$ of the bootstrap values in both MP and NJ trees.

\section{Discussion}

Previous molecular and morphological systematic studies (Lee and Downie, 1999; 2000; Lee et al., 2001) of tribe Caucalideae revealed that the monophyly of the genus was not suggested. Expanded sampling of Daucus species in this study supports the previous studies showing not monophyly of the genus Daucus. Here, we discuss the monophyly of Pseudorlaya, sectional relationships within Daucus, and phylogenetic relationships of each species investigated.

\section{Monophyly of the genus Pseudorlaya}

Morphologically, Pseudorlaya is distinguished from Daucus in having two rows of fruit secondary spines instead of one (Davis, 1972; Zohary, 1972). This justifies the transfer of D. biseriatus to Pseudorlaya by Sáenz de Rivas and Heywood (1974). Molecular phylogeny derived from ITS sequences of all the species of Pseudorlaya including $P$. biseriatus and $P$. minuscula does not support monophyly of the genus. Failure of monophyly of the genus suggests that the number of spine arrangements is not a good character to delimit the generic boundary of Pseudorlaya. Furthermore, Lee et al. (2001) reported that these paired spines are alternate with single ones in Pseudorlaya pumila. Additional evidence from molecular phylogenies, along with other information, suggests that arrangement rows of secondary spines be not enough to retain Pseudorlaya as a distinct genus. Another diagnostic character for Pseudorlaya is dome-shaped primary ridges (Lee et al., 2001). However, P. minuscula is not obviously widened at the fruit base from recent observation of the type material (Arnold and Jury, 1996). Otherwise, Pseudorlaya is very similar to Daucus, both morphologically and chemically (Harborne et al., 1969; Heywood and Dakshini, 1971; Williams and Harborne, 1972) and thus might be included within the genus Daucus.

\section{Sectional relationships within the genus Daucus}

Most classification systems of the family Apiaceae rely on a diverse array of subtle fruit differences to demarcate major taxonomic groups. However, serious doubts have been raised on the phylogenetic utility of these characters
(Theobald, 1971; Davis, 1972; Jury, 1982; Shneyer et al., 1992). Considering the genus Daucus, each section possesses a unique set of fruit surface features (Heywood and Dakshini, 1971; Sáenz de Rivas et al., 1982). These characters, while permitting the easy recognition of species, are less useful in providing information on infrageneric relationships. Heywood and Jury's (in Heywood, 1982) division of the genus into seven sections which is largely refinement of Thellung's (1926) treatment is most commonly used. Section Daucus has been considered unnatural in a sense that several species were placed in the section primarily based on the superficial similarity of morphological and anatomical characters, as mentioned by Heywood (1971). In observation of microcharacters of fruits, Heywood and Dakshini (1971) found that morphological features of some species overlap with those of other sections of the genus, suggesting that section Daucus seems not to be natural. However, on the basis of morphological similarities in relative length of spines to width of the mericarp, degree of connation at the base of spines, length of styles, and anatomical features of the fruits, Okeke (1977) and Heywood (1982) recognized 11 species within the section. Based on our results using nine species of the section, sect. Daucus is not monophyletic because D. tenuisectus, D. guttatus, and $D$. involucratus are closely related to other sections. Section Anisactis includes Daucus durieua, D. glochidiatus, D. hochstetteri, and D. montanus (Heywood, 1982). The umbel characters of D. durieua, D. glochidiatus, and $D$. hochstetteri are remarkably distinct from those of other sections. They include axillary umbels, few rays, whorled cauline leaves, and lack of peduncles and normal bracts, suggesting close relationships among these three species (Okeke, 1978). Results of our molecular phylogenies, however, do not support the monophyly of the section because $D$. durieua is not included within. Daucus species in the New World (i.e., D. pusillus and D. montanus) were treated separately into different sections based on the shape of vittae (Thellung, 1926; Sáenz, 1981; Heywood, 1982), which is consistent with phylogenies derived from ITS sequences herein. However, the phylogenies inferred from the morphology and chloroplast DNA restriction variation suggest the close relationship between two taxa based on all perfect flowers and obsolete calyx teeth, and five nonhomoplastic chloroplast DNA restriction site variation (Lee and Downie, 2000; Lee et al., 2001). D. glochidiatus, endemic to Australia, showed the close relationships with South American D. montanus. These two species share polyploidy of $x=11$ as well as morphological and anatomical characters of fruits (Okeke, 1978). Section Meoides contains D. crinitus and D. setifolius and is characterized by the presence of unique pseudo-verticillate leaf arrangement, perennial vegetation, and the absence of glochidiate apex on the secon- 
dary spines. However, Sáenz (1981) incorporated D. crinitus into section Daucus on the basis of similarity of the large and triangular-shaped vittae, leaving $D$. setifolius as the sole member of Meoides. Our results do not confirm Sáenz's (1981) transfer of D. crinitus into section Daucus because the close relationship between them was not supported. From the result, it can be assumed that the large and triangular-shaped vittae seen in many members of section Daucus have arisen independently. The results of molecular phylogenies investigated herein agree generally with the recognition and independent separation of each of Heywood's (1982) mono- or di-typic sections (i.e., sections Chrysodaucus, Platyspermum, Leptodaucus, and Pseudoplatyspermum) within the genus. The close relative of section Chryodaucus is suggested to be section Platyspermum from recent phylogenetic studies using morphological characters (Lee et al., 2001). This result is consistent with Okeke's (1978) classification system which treated D. aureus (sect. Chrysodaucus) as a member of sect. Platyspermum. Although these two sections share closely located vascular bundles on the commissural surface, reduced elliptic vittae, and sclerenchymatous cells between their commissural vittae (Okeke, 1978), our molecular phylogenies do not support the union between these two sections. Homologically, section Chrysodaucus including D. aureus is distinct from other sections in having overwhelmingly swollen calyx below the stylopodium, and varying degrees of heterocarpic fruits. In addition, the section develops strong secondary spines with glochidiate apex around the outmost margins of the umbel whereas it has very shortened secondary spines without glochidiate apex in inner areas of the same umbel. Section Platyspermum is unique in particularly large size of fruits and strong confluence at the base of secondary spines whereas section Pseudoplatyspermum can be distinguished from all other Daucus species by shapes of bracts. Bracts of the section are trifid rather than pinnatisect or leaf-like, and the unique color of its rays and styles (Okeke, 1982; Lee et al., 2001). Emphasizing the presence of the triangular shape of vittae, Okeke (1978) and Sáenz (1981) treated American endemic D. pusillus as a member of European section Daucus. However, ITS molecular phylogenies do not support the inclusion of D. pusillus into section Daucus showing closer relationship among $D$. pusillus, sections Anisactis and Pseudoplatyspermum.

\section{Species relationships of the genus Daucus}

The ITS phylogeny recognizes two major clades within the genus, with some Daucus species allied with all the species of Pseudorlaya and Pachyctenium mirabile, and others with Agrocharis. Taxonomic delimitation of each Daucus species will be discussed in the following sections.

Daucus carota: The delimitation of Daucus carota L. has been one of the most confused problems in Apiaceae classification because well-defined sterility barriers have not been developed among subspecies of $D$. carota, and even between $D$. carota and its relative species (i.e., $D$. capillifolius), often leading to viable hybrid progenies (McCollum, 1975; 1977; Small, 1978; Debonte et al., 1984). Thellung (1926) and Ono (1936) recognized two groups (Gummiferi and Eucarota) on the basis of shapes of fruiting umbels, fleshiness and shininess of the leaf, and dissection degree in leaf segments and bracts. In the most recent classification system of $D$. carota comlex, Heywood (1983) recognized 13 subspecies which were assigned into two groups. Of Heywood's subspecies of D. carota, Carota group includes subspecies carota, sativus, azoricus, maritimus, and major whereas the other Gingidium group contains other remaining subspecies (i.e., gadecaei, gummifer, drepanensis, and hispanicus). Upon consideration of available ITS sequences, group separation among Daucus carota is not supported because D. carota ssp. azoricus was nested within the group Gingidium. Not enough variation of ITS sequences among subspecies of $D$. carota indicates that these sequences are less useful in resolving intraspecifc relationships within D. carota. No clear pattern of division is consistent with results derived from phytochemical (Williams and Harborne, 1972), karyotype (Owens, 1974; McCollum, 1975), and morphological studies (Small, 1978). As suggested in isozyme analyses (Pierre et al., 1990), subspecies of $D$. carota may be a young taxa in terms of evolutionary history with marginal groups have not yet been separated genetically from each other.

Daucus capillifolius: Morphologically, D. capillifolius is distinctive from $D$. carota by having glabrous 2- to 3pinnatisect leaves with filiform segments. The ITS phylogeny investigated herein does not support separation of $D$. capillifolius from $D$. carota, showing that $D$. capillifolius is nested within the latter. The close relationship between $D$. capillifolius and $D$. carota is also suggested by a hybridization study performed by McCollum (1975; 1977). He and his colleagues were able to produce hybrids between $D$. capillifolius and some subspecies of $D$. carota. Although morphological, anatomical, and phytochemical variation between $D$. carota and $D$. capillifolius is extensive, successful hybridization and close phylogenetic relationships between $D$. carota and $D$. capillifolius raise some doubts on the specific status of $D$. capillifolius, and thus it maybe treated as a subspecies of the Daucus carota.

Daucus syrticus, D. gracilis, and D. sahariensis: Although Daucus syrticus, D. gracilis, and D. sahariensis 
did not form a clade in the MP and ML trees, they are probably the most closely related plants to $D$. carota. These three north African and east Mediterranean species are characterized morphologically by the presence of linear to filiform leaf segments, irradiated petals on the scattered umbels, and the same base chromosome number $(\mathrm{x}=9)$ as those of $D$. carota and D. capillifolius. The sister relationship of $D$. syrticus to $D$. carota sensu lato strongly supported from ITS phylogeny is also congruent to the results of a cytological study. In the comparison of karyotype morphology among seven species of Daucus (Owens, 1984), the general similarities were found between $D$. carota and D. syrticus, reflecting that the two species can be hybridized potentially to improve germplasm of D. carota sensu lato.

D. involucratus and D. guttatus: The second clade of plants within Daucus, allied with Agrocharis, is supported strongly with a high bootstrap value of $96 \%$ and decay index of six in the MP tree. Preliminary investigation of morphological and anatomical characters on genus Daucus reveals that the number of rows of primary hairs (i.e., over three rows) is a probable character to support, in part, the relationships among these plants. Two species of Daucus (i.e., D. involucratus and D. guttatus) were treated as members of section Daucus by Heywood (1982), but they did not show close relationships with any species of the section in the ITS phylogeny. Furthermore, careful observation on overall morphology identified several morphological characters to support the separation of these two species from section Daucus. One of them is the floral structure. D. involucratus is remarkably similar in the floral structure to those of D. durieua, D. glochidiatus, D. hochstetteri, D. montanus and D. pusillus. Their petals are minute and tend to be unlobed at the apex, and their styles are very short. The fruit of D. guttatus shows a remarkable development of tubercules which were not observed in any species of the section Daucus. Strongly tuberculated spine is one of the most conspicuous features in delimiting section Anisactis. The close relationship between $D$. guttatus and section Anisactis is also congruent to results of phytochemical investigations (Okeke, 1978). D. guttatus and D. durieua contain a flavonol, kaempferol whereas other species of section Daucus have either flavones (e.g., luteoline, apigenin) or a flavonol (e.g., quercetin). These morphological and phytochemical pecularities of $D$. involucratus and D. guttatus which are not met elsewhere in the section Daucus provide further support for inclusion of these two species within the Anisactis clade.

Daucus conchitae and D. arcanus: Daucus conchitae, established by Greuter (1979), was suggested to fall outside the range of morphological variation of the putatively related D. guttatus and D. involucratus. Greuter (1979) proposed that the closely related species of $D$. conchitae might be D. involucratus on the basis of similarities in general habit. The results of molecular phylogenies investigated here support the close relationship between these two species, with $100 \%$ and $98 \%$ bootstrap values in MP and $\mathrm{NJ}$ trees, respectively. However, low divergence values $(0.48 \%)$ of ITS sequences between $D$. conchitae and $D$. involucratus indicate that they were separated relatively recently. Daucus arcanus, another new species recently established from southern Spain by Martin and Silvestre (1990), is closely related to north American $D$. pusillus. Despite long distance between habits of these species, the sequence divergence of ITS is extremely low, less than $1 \%$. Morphologically, these two species are very similar to each other except the much smaller size of $D$. arcanus. They also share a base chromosome number of eleven. To date, other molecular information is not available for D. arcanus, but we consider that this new species may be infraspecific taxon of $D$. pusillus. The fruits of genus Daucus are dispersed by wind and animals (Lacey, 1981). The smallness, dryness and lightness of the fruits render them easily wind-borne. The fruits may also be carried on animal fur, attached by their hooked spines, tubercles and spine barbs (Okeke, 1978). The latter may be responsible for the introduction of $D$. pusillus from America to parts of Europe (i.e., Spain) as D. carota subsp. carota, a Mediterranean taxon, to most areas of the world, and Australian Daucus glochidiatus to most parts of Europe (Okeke, 1978).

Phylogenetic analyses using nuclear ribosomal DNA ITS sequences reveal that the genus Daucus is not monophyletic with genera Pseudorlaya, Pachyctenium, and Agrocharis nested within. Two groups within Daucus and a group comprising exclusively Agrocharis were recognized from the analysis; we have provisionally named these three groups the Daucus, Anisactis, and Agrocharis clades until more formal nomenclature can be applied. We are continuing our investigation of genus Daucus phylogeny by examining data from the chloroplast genome. Detailed morphological and anatomical investigations are also underway, and when completed will provide insight into character evolution, including the identification of morphological synapomorphies supporting each of the major clades identified herein on the basis of ITS data. Additional data from both chloroplast DNA and morphology are currently being pursued in order to clarify relationships within the polymorphic Daucus and their close relatives, such as Pseudorlaya, Pachyctenium, and Agrocharis.

\section{ACKNOWLedgements}

The authors thank Dr. Stephen R. Downie, Deborah 
Katz-Downie, Randall J. Bayer, and many botanical gardens cited in the text for generously providing us with leaf, seed, or DNA material. Research was supported by a grant (PF001302-00) from plant diversity research center of 21 st century frontier research program funded by the Ministry of Science and Technology of Korean Government.

\section{REFERENCES}

Arnold, B. and S.L. Jury. 1996. Delimitation of Pseudorlaya taxa. Lagascalia 18(2):285-286.

Baum, D.A., K.J. Systma and P.C. Hoch. 1994. A phylogenetic analysis of Epilobium (Onagraceae) based on nuclear ribosomal DNA sequences. Systematic Botany 19:363388.

Bentham, G. and J.D. Hooker. 1867. Umbelliferae. In: G. Bentham and J.D. Hooker (eds.), Genera Plantarum 1. Reeve, London. pp. 859-931.

Calestani, V.H. 1905. Contributo alla systematica delle ombellifere d'europa. Webbia 1:89-280.

Cheeseman, T.F. 1925. Daucus. In: T.F. Cheeseman (ed.), Manual of the New Zealand Flora, Wellington. pp. 684685.

Davis, P.H. 1972. Umbelliferae. In: P.H. Davis (ed.), Flora of Turkey and the East Aegean Islands, vol. 4. The University Press at University of Edinburgh, Edinburgh. pp. 265-538.

Debonte, L.R., B.F. Matthews and K.G. Wilson. 1984. Variation of plastid and mitochondrial DNAs in the genus Daucus. American Journal of Botany 71:932-940.

Downie, S.R. and D.S. Katz-Downie. 1996. A molecular phylogeny of Apiaceae subfamily Apioideae: evidence from nuclear ribosomal DNA internal transcribed spacer sequences. American Journal of Botany 83:234-251.

Downie, S.R., D.S. Katz-Downie and K. Spalik. 2000. A phylogeny of Apiaceae tribe Scandiceae: evidence from nuclear ribosomal DNA internal transcribed spacer sequences. American Journal of Botany 87:76-95.

Drude, O. 1898. Umbelliferae. In: A. Engler and K. Prantl (eds.), Dienatüralichen pflanzenfamilien 3. Wilhelm Engelmann, Leipzig. pp. 63-250.

Eriksson, T. 1997. AutoDecay version 2.9.9 (hypercard-stack computer program distributed by the author). Botaniska Institutionem, Stockholm University, Stockholm.

Farris, J.S. 1989. The retention index and homoplasy excess. Systematic Zoology 38:406-407.

Felsenstein, J. 1981. Evolutionary trees from DNA sequences: A maximum likelihood approach. Journal of Molecular Evolution 17:368-376.

Felsenstein, J. 1985. Confidence limits on phylogenies: an approach using the bootstrap. Evolution 39:783-791.

Felsenstein, J. 1993. PHYLIP (Phylogeny Inference Package) version 3.572. Distributed by the author. Department of Genetics, University of Washington, Seattle.

Greuter, W. 1979. The flora and phytogeography of Kastellorizo (Dhodhekanisos, Greece). Willdenowia 8:531-611.

Harborne, J.B. 1967. Comparative biochemistry of flavonoids - V. Luteolin 5-Glucoside and its occurrence in the Umbelliferae. Phytochemistry 6:1569-1573.

Harborne, J.B., V.H. Heywood and C.A. Williams. 1969. Distribution of Myristicin in seeds of the Umbelliferae. Phytochemistry 8:1729-1732.

Heywood, V.H. 1971. The characteristics of the scanning electron microscope and their importance in biological studies. In: V.H. Heywood (ed.), The Biology and Chemistry of the Umbelliferae, Supplement 1 to the Botanical Journal of the Linnean Society, Vol. 64, Academic Press, New York. pp. 1-16.

Heywood, V.H. 1973. The taxonomic position of Agrocharis Hochst. and allied genera. Notes Royal Botanic Garden, Edinburgh 32:211-215.

Heywood, V.H. 1978. Flowering plants of the World. Oxford University Press, Oxford.

Heywood, V.H. 1982. Multivariate taxonomic synthesis of the tribe Caucalideae. In: A.-M. Cauwet-Marc and J. Carbonnier (ed.), Les Ombellifères. Actes du 2ème Symposium International sur les Ombellifères "Contributions Pluridisciplinaires à la Systématique.", Monographs in Systematic Botany from the Missouri Botanical Garden, vol. 6, Braun-Brumfield, Ann Arbor. pp. 727-736.

Heywood, V.H. 1983. Relationships and evolution in the Daucus carota complex. Israel Journal of Botany 32:5165.

Heywood, V.H. 1986. The Umbelliferae - an impossible family? Symbolae Botanicae Upsalienses 26:173-180.

Heywood, V.H. and K.M.M. Dakshini. 1971. Fruit Structure in the Umbelliferae - Caucalideae. In: V.H. Heywood (ed.), The Biology and Chemistry of the Umbelliferae, Supplement 1 to the Botanical Journal of the Linnean Society, vol. 64, Academic Press, New York. pp. 215-232.

Hiern, W.P. 1877. Agrocharis. In: D. Oliver (ed.), Flora of Tropical Africa 3. Lovell Reeve \& Co., London. pp. 2627.

Higgins, D.G., A.J. Bleasby and R. Fuchs. 1992. CLUSTAL $\mathrm{V}$ : Improved software for multiple sequence alignment. Computer Applications in the Bioscience 8:189-191.

Holmgren, P.K., N.H. Holmgren and L.C. Barnet. 1990. Index herbariorum. New York Botanical Garden, New York.

Jacques-Félix, H. 1970. Ombellales. In: A. Aubréville and J.-F. Leroy (eds.), Flore du Cameroun, 10. Paris.

Jury, S.L. 1982. Tuberculate fruits in the Umbelliferae, tribe Caucalideae. In: A.-M. Cauwet-Marc and J. Carbonnier (eds.), Les Ombellifères. Actes du 2ème Symposium International sur les Ombellifères "Contributions Pluridisciplinaires à la Systématique.”, Monographs in Systematic Botany from the Missouri Botanical Garden, vol. 6. Braun- 
Brumfield, Ann Arbor. pp. 149-159.

Jury, S.L. 1986. Fruit and leaf variation in the African species of the Umbelliferae tribe Caucalideae. Symbolae Botanicae Upsalienses 26:181-186.

Katz-Downie, D.S., C.M. Valiejo-Roman, E.I. Terentieva, A.V. Troitsky, B. Lee and S.R. Downie. 1999. Towards a molecular phylogeny of Apiaceae subfamily Apioideae; additional information from nuclear ribosomal DNA ITS sequences. Plant Systematics and Evolution 216:167-195.

Kimura, M. 1980. A simple method for estimating evolutionary rates of base substitution through comparative studies of nucleotide sequences. Journal of Molecular Evolution 16:111-120.

Kluge, A.G. and J.S. Farris. 1969. Quantitative phyletics and evolution of anurans. Systematics Zoology 18:1-32.

Koso-Poljansky, B.M. 1916. Sciadophytorum systematis lineamenta. Bulletin de la Société Impériale des Naturalistes, Moscow 29:93-222.

Koso-Poljansky, B.M. 1917. Sciadophytorum systematis lineamenta Mantissa prior. Bulletin de la Société Impériale des Naturalistes, Moscow 30:277-290.

Lacey, E.P. 1981. Seed dispersal in wild carrot (Daucus carota). The Michigan Botanist. 15-20.

Lee, B.-Y. and S.R. Downie. 1999. A molecular phylogeny of Apiaceae tribe Caucalideae and related taxa: inferences based on ITS sequence data. Systematic Botany 24:461479.

Lee, B.-Y. and S.R. Downie. 2000. Phylogenetic analysis of cpDNA restriction sites and rps 16 intron sequences reveals relationships among Apiaceae tribes Caucalideae, Scandiceae and related taxa. Plant Systematics and Evolution 221:35-60.

Lee, B.-Y., G.A. Levin and S.R. Downie. 2001. Relationships within the spiny-fruited Umbellifers (Scandiceae subtribes Daucinae and Torilidinae) as assessed by phylogenetic analysis of morphological characters. Systematic Botany 26:622-642.

Maddison, W.P. and D.R. Maddison. 1992. MacClade version 3.0: analysis of phylogeny and character evolution. Sinauer, Sunderland.

Martin, F.G. and S. Silvestre. 1990. Una nueva especie de Daucus (Umbelliferae) de anadalucia occidental. Lagascalia 15:263-268.

McCollum, G.D. 1975. Interspecific hybrid Daucus carota and D. capillifolius. Botanical Gazette 136:201-206.

McCollum, G.D. 1977. Hybrids of Daucus gingidium with cultivated carrots (D. carota subsp. sativus) and D. capillifolius. Botanical Gazette 138:56-63.

Norman, C. 1934. Notes on tropical African Umbelliferae. Journal of Botany (London) 72:205-206.

Okeke, S.E. 1978. Systematic studies in Daucus L. (Umbelliferae). Ph. D. Thesis of the University of Reading, Reading.

Okeke, S.E. 1982. Morphological variation of bracts, bracte- oles and fruits in Daucus L. In: A.-M. Cauwet-Marc and J. Carbonnier (eds.), Les Ombellifères. Actes du 2ème Symposium International sur les Ombellifères "Contributions Pluridisciplinaires à la Systématique.”, Monographs in Systematic Botany from the Missouri Botanical Garden, vol. 6, Braun-Brumfield, Ann. Arbor. pp. 161-174.

Olsen, G.J., H. Matsuda, R. Hagstrom and R. Overbeek. 1994. Fast DNAml: A tool for construction of phylogenetic trees of DNA sequences using maximum likelihood. Computer Applications in the Biosciences 10:41-48.

Onno, M. 1936. The wild forms of Daucus section Carota (in German). Beiheftezum Botanischen Zentralblatt 56:83136.

Owens, S.J. 1974. An examination of the floral biology, breeding system and cytology in species of the genus Daucus and related genera in tribe Caucalideae (Umbelliferae). Ph.D. Thesis of the University of Reading, Reading.

Pierre, M.D., R.J. Randall and I.M. Bayer. 1990. An isozymebased assessment of the generic variability within the Daucus carota complex (Apiaceae: Caucalideae). Canadian Journal of Botany 68:2449-2457.

Sáenz, C. 1981. Research on Daucus L. (Umbelliferae). Anales des Instituto Botánico A. J. Cavanilles 37:481-533.

Sáenz de Rivas, C. and V.H. Heywood. 1974. Estudio preliminar sobre los Daucus de la España Peninsular. Anales des Instituto Botánico A. J. Cavanilles 31:97-118.

Sáenz de Rivas, C., V.H. Heywood, S. Jury and A. Al-Attar. 1982. Etude micromorphologique et anatomique du fruit des Caucalideae Bentham (Umbelliferae). In: A.-M. Cauwet-Marc and J. Carbonnier (eds.), Les Ombellifères. Actes du 2ème Symposium International sur les Ombellifères "Contributions Pluridisciplinaires à la Systématique.", Monographs in Systematic Botany from the Missouri Botanical Garden, vol. 6. Braun-Brumfield, Ann Arbor. pp. 175-193.

Saitou, N. and M. Nei. 1987. The neighbor-joining method: a new method for reconstructing evolutionary trees. Molecular Biology and Evolution 4:406-425.

Shneyer, V.S., G.P. Borschtschenko, M.G. Pimenov and M. V. Leonov. 1992. The tribe Smyrnieae (Umbelliferae) in the light of serotaxonomical analysis. Plant Systematics and Evolution 182:135-148.

Small, E. 1978. A numerical taxonomic analysis of the Daucus carota complex. Canadian Journal of Botany 56:249-276.

Swofford, D.L. 2000. PAUP*. Phylogenetic Analysis Using Parsimony, version 4.0. Sinaur Associates, Sunderland.

Thellung, A. 1926. Die Linneschen Daucus-Arten in Lichte der original-Herbarexemplare. Repertorium Specierum Novarum Regni Vegetabilis 22:300-315.

Theobald, W.L. 1971. Comparative anatomical and developmental studies in the Umbelliferae. In: V.H. Heywood (ed.), The Biology and Chemistry of the Umbelliferae, Supplement 1 to the Botanical Journal of the Linnean Society. vol. 64. Academic Press, New York. pp. 171- 
179.

White, T.J., T. Bruns, S. Lee and J. Taylor. 1990. Amplification and direct sequencing of fungal ribosomal RNA genes for phylogenetics. In: M.A. Innis, D.H. Gelfand, J.J. Sninsky and T.J. White (eds.), PCR Protocols: a Guide to Methods and Applications, Academic Press, San Diego. pp. 315-322.
Williams, C.A. and J.B. Harborne. 1972. Essential oils in the spiny-fruited Umbelliferae. Phytochemistry 11:1981-1987.

Zohary, M. 1972. Umbelliferae. In: M. Zohary (ed.), Flora Palaestina, Part 2. Goldberg's press, Jerusalem. pp. 378460.

Submitted: November 29, 2013, Accepted: January 9, 2014 